\title{
Minat Berwirausaha Sosial Dikalangan Mahasiswa
}

\section{Purbo Jadmiko}

Universitas Bung Hatta

purbojadmiko@bunghatta.ac.id

\begin{abstract}
This study aims to determine the direct effect of empathy and social support on the social entrepreneurship intention at Bung Hatta University students. A total of 208 samples were used in this study. The results of research testing show that empathy has no effect on interest in social entrepreneurship. While social support shows a positive and significant effect on social entrepreneurial interest. Discussions on the model of forming social interest in entrepreneurship among students were discussed in this study.
\end{abstract}

\section{Keywords: empaty; perceived social support; social entrepreneurial intention}

\section{ABSTRAK}

Penelitian ini bertujuan untuk mengetahui pengaruh langsung (direct effect) pengaruh empati dan dukungan sosial terhadap minat berwirausaha sosial pada mahasiswa Universitas Bung Hatta. Sebanyak 208 sampel digunakan dalam penelitian in. Hasil pengujian penelitian menunjukkan bahwa empati tidak berpengaruh terhadap minat berwirausaha sosial. Sedangkan dukungan sosial menunjukkan positif dan signifikan berpengaruh terhadap minat berwirausaha sosial. Diskusi mengenai model pembentukan minat berwirausaha sosial dikalangan mahasiswa didiskusikan pada penelitian ini.

Kata Kunci: empati; dukungan sosial; minat berwirausaha sosial 


\section{PENDAHULUAN}

Pandangan entreprenuer business yang tidak mengedepankan isu lingkungan dan sosial tampaknya mulai mendapatkan kritik oleh berbagai pihak. Isu tersebut muncul karena masih banyak para pelaku usaha yang fokus pada profit semata, tanpa memperdulikan sosial disekitar. Hal ini menjadikan peran entreprenuer business tampaknya tidak menjadi pilihan untuk masa depan yang berkelanjutan (Bocken et al., 2014). Oleh sebab itu, dibutuhkan model bisnis baru yang menjunjung tinggi nilai-nilai sosial. Artinya, pelaku usaha harus mulai memfokuskan dari profit ke people. Menurut Boons \& Lüdeke-freund (2013), model bisnis yang berkelanjutan menawarkan pendekatan inovatif untuk membawa perubahan yang diinginkan melalui rekonseptualisasi misi perusahaan dan penciptaan nilai sosial.

Salah satu model bisnis yang memiliki misi sosial ialah kewirausahaan sosial. Kewirausahaan sosial dipandang dapat memberi solusi permasalahan sosial saat ini. Business entreprenuer hanya berfokus terhadap profit serta kepuasan pelanggan, berbeda halnya dengan kewirausahaan sosial yakni lebih berfokus terhadap tujuan sosial/nilai sosial (Mair et al., 2006:1).

Istilah kewirausahaan sosial dikenalkan oleh Bill Drayton (pendiri Ashoka Foundation) pada tahun 1972. Kewirausahaan sosial menjadi trend dunia ketika Muhammad Yunus memperoleh Nobel Perdamaian pada tahun 2006 (Garmen Bank untuk pengembangan kredit mikro dan bisnis sosial di negara Bangladesh). Menurut Utomo (2014), wirausaha sosial fokus melihat masalah menjadi sebuah peluang (pemberdayaan masyarakat menjadi model bisnis baru).

Di Indonesia sendiri, pendidikan kewirausahaan sosial telah diusung pada konsep "Merdeka Belajar" yang digagas oleh Menteri Pendidikan dan Kebudayaan Nadiem Makarim. Pada buku pedoman penyusunan kurikulum merdeka belajar (2020) menekankan bahwa berdasarkan IDN Research Institute tahun 2019, 69,1\% millennial di Indonesia memiliki minat untuk berwirausaha. Namun, potensi wirausaha bagi generasi milenial tersebut belum dapat dikelola dengan baik selama ini. Khususnya generasi milenial seperti mahasiswa. Pada Buku Pendoman Merdeka Belajar Tahun tersebut juga fokus pada kewirausahaan sosial (hal. 20).

Hibbert et al. (2005) mengungkapkan bahwa kewirausahaan sosial adalah pemanfaatan perilaku kewirausahaan yang lebih berorientasi untuk pencapaian tujuan sosial dan tidak mengutamakan perolehan laba, atau laba yang diperoleh dimanfaatkan untuk kepentingan sosial. Sedangkan menurut (Mair et al., 2006:1) konsep kewirausahaan sosial bertujuan pada bisnis yang didedikasikan untuk misi sosial atau sektor nirlaba. Kewirausahaan sosial merupakan istilah yang digunakan untuk menggambarkan pendekatan inovatif untuk 
mengatasi masalah sosial (Desa, 2010). Wirausahawan sosial adalah untuk memenuhi misi sosial mereka (Abu-saifan, 2012).

Misi dan menciptakan nilai sosial menjadi kunci tujuan dari kewirausahaan sosial. Hal ini dipertegas oleh definisi (Hulgard, 2010) bahwa kewirausahaan sosial didefinisikan sebagai penciptaan nilai sosial yang tercipta karena kolaborasi dengan orang dan organisasi dari masyarakat umum yang juga terlibat dalam kegiatan ekonomi inovasi sosial. Defenisi (Hulgard, 2010) tersebut menyimpulkan bahwa kewirausahaan sosial setidaknya terdiri atas empat elemen utama meliputi social value, civil society, innovation, dan economic avtivity: 1) social value merupakan elemen kunci dari kewirausahaan sosial yakni menciptakan manfaat sosial yang nyata bagi masyarakat dan lingkungan sekitar; 2) civil society ialah kolaborasi dan inisiatif dari partisipasi masyarakat sipil dengan mengoptimalkan modal sosial di masyarakat; 3) innovation merupakan kontribusi sosial dalam memecahkan permasalahan sosial dengan cara-cara yang inovatif seperti memadukan kearifan lokal dan inovasi sosial; dan 4) economic activity adalah keseimbangan antara misi sosial dan aktvitas bisnis yang tidak bisa dilepaskan dari keduanya.

Hingga saat ini, penelitian mengenai minat kewirausahaan sosial telah mulai banyak diteliti. Namun demikian, penelitian yang menggunakan responden mahasiswa masih belum banyak dikaji. Penelitian yang telah banyak diteliti maish fokus pada minat berwirausaha, belum spesifik pada kewirausahaan sosial. Minat berwirausaha sosial dikalangan mahasiswa menjadi hal penting dimana peran mahasiswa sebagai agent of change dimasyarakat sangat dinanti dan dibutuhkan untuk mengatasi berbagai persoalan sosial. Selain itu, generasi melenial kini tumbuh diera digitalisasi dan otomasi yang memungkinkan untuk menciptakan misi dan nilai sosial melalui innovasi bisnis sosial.

Beberapa penelitian mengenai faktor-faktor yang mempengaruhi minat berwirausaha sosial dikalangan mahasiswa telah diteliti sebelumnya. Seperti penelitian yang dilakukan oleh oleh Hockerts (2017) yakni peran empati seseorang berpengaruh positif terhadap minat berwirausaha sosial dikalangan mahasiswa. Semakin tinggi empati yang dimiliki oleh mahasiswa, semakin tinggi niatan mereka untuk berwirausaha sosial. Persepsi empati terhadap persoalan sosial mendorong seseorang berniat menjadi seorang wirausahawan sosial. Selaras dengan temuan penelitian (Rashid et al., 2018) menemukan bahwa prior experience dan efikasi diri berpengaruh positif terhadap minat kewirausahaan sosial. Faktor pengalaman berwirausaha juga berkontribusi dalam meningkatkan minat seseorang untuk menjadi wirausahawan sosial.

Selanjutnya, terdapat beberapa studi tentang minat kewirausahaan yang menggunakan 
model Planned Behaviour Theory (Ajzen, 1991) sebagai perumusan kerangka konseptual penelitian. Perspektif Planned Behaviour Theory merupakan serangkaian proses perencanaan perilaku seseorang sebelum bertindak. Perspektif Planned Behaviour Theory juga menunjukkan bahwa perilaku niatan seseorang tidak langsung dipengaruhi oleh variabel antecendent, namun dimediasi (mediators) oleh niatan sikap seseorang (Tiwari, et al., 2017b).

Dengan demikian, studi mengenai minat berwirausaha sosial terdapat inkonsistensi dalam merumuskan model penelitian. Meskipun demikian, terdapat studi dimana empati, efikasi diri dan persepsi dukungan sosial mempengaruhi secara langsung (direct effect) terhadap minat berwirausaha sosial (Hockerts, 2017). Inkonsistensi tersebut menjadi gap penelitian ini, apakah pengaruh variabel antecedent bersifat indirect effet terhadap minat berwirausaha sosial. Penelitian ini bertujuan untuk membuktikan kesenjangan hasil penelitian mengenai minat berwirausaha sosial dikalangan mahasiswa.

\section{Empati Terhadap Minat Berwirausaha Sosial}

Minat berwirausaha sosial yakni perilaku psikologis manusia dalam mempengaruhi orang lain untuk mengumpulkan pengetahuan, memahami ide-ide dan melaksanakan rencana bisnis sosial untuk menjadi seorang wirausahawan sosial (Mair et al., 2006). Beberapa penelitian tentang minat berwirausaha sosial telah banyak diteliti. Beberapa penelitian masih fokus mengenai faktor-faktor yang mempengaruhi minat berwirausaha sosial baik pengaruh langsung maupun pengaruh tidak langsung. Penelitian yang dilakukan oleh (Ayob et al., 2013) menemukan bahwa empati yang dipersepsikan oleh pembisnis dan mahasiswa ekonomi dari beberapa perguruan tinggi negeri maupun swasta di Malaysia ditemukan bahwa empati berpengaruh positif terhadap minat berwirausaha sosial. Semakin tinggi tingkatan empati yang dipersepsikan oleh mahasiswa, semakin tinggi kecenderungan untuk berniat menjadi wirausahawan sosial. Meskipun pada konteks penelitian lain empati tidak berpengaruh positif terhadap minat berwirausaha sosial (Rashid et al., 2018). Berdasarkan uraian hasil penelitian diatas, dirumuskan hipotesis ke-1 sebagai berikut:

\section{$H_{1}:$ Empati berpengaruh positif terhadap minat berwirausaha sosial Empati}

Dukungan sosial yang dirasakan adalah anteseden penting lain yang mendorong pembentukan niat perilaku untuk memulai usaha sosial (Mair dan Noboa, 2006). Dukungan sosial sangat penting karena membantu individu dalam mencapai hasil kewirausahaan sosial yang lebih spesifik (Hockerts, 2015). Penelitian Lacap et. al., (2018) menunjukkan bahwa dukungan sosial yang dipersepsikan sebagai wirausaha sosial secara signifikan dan positif 
terkait dengan niat wirausaha sosial (kasus mahasiswa Filipina dan Indonesia). Hasil ini menunjukkan bahwa dukungan sosial yang dirasakan oleh mahasiswa akan memicu niat kewirausahaan sosial mereka. Mair dan Noboa (2006) dan Hockerts (2017) juga menemukan bahwa dukungan sosial memprediksi niat wirausaha sosial. Oleh karena itu, dirumuskan hipotesis ke-2 sebagai berikut:

\section{$\mathrm{H}_{2}$ : Persepsi dukungan sosial berpengaruh positif terhadap niat wirausaha sosial}

Berdasarkan pemaparan dan kajian literatur di atas maka kerangka konseptual penelitian disajikan pada Gambar 1 sebagai berikut.

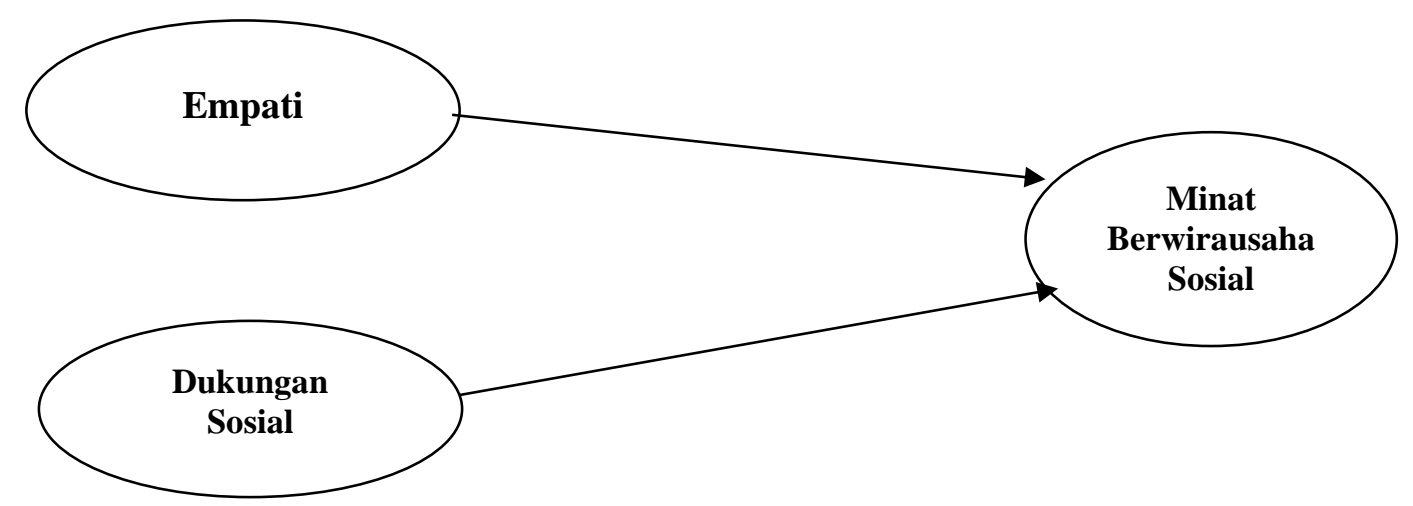

Gambar 1. Model Kerangka Konseptual Penelitian

\section{METODE PENELITIAN}

Desain penelitian ini adala penelitian kuantitatif dengan metode survei. Menurut Cooper dan Schinder (2014) metode survei merupakan salah satu metode pengumpulan data primer yang dapat dilakukan secara cermat, sistematis dan terstruktur. Sampel penelitian ini adalah mahasiswa Fakultas Ekonomi dan Bisnis Universitas Bung Hatta. Metode purposve sampling digunakan untuk menentukan sampel penelitian. Adapun kriteria yakni mahasiswa yang telah menempuh minimal 2 semester $(n=208$ sampel $)$.

Definisi operasional variabel empati dan minat berwirausaha sosial menggunakan definisi yang dikembangkan oleh Hockerts (2015). Empati didefinisikan sebagai persepsi emosi seseorang sehubungan dengan subjek yang ingin dibantu (biasanya orang yang terpinggirkan). Sedangkan Minat berwirausaha sosial Keyakinan seseorang terhadap keinginan, tekad untuk mendirikan perusahaan sosial. Dukungan sosial didefinisikan sebagai dukungan formal dan informal yang dirasakan ketika seseorang menjalankan usaha. Semua variabel penelitian menggunakan 5 skala Likert.

Pengujian validitas menggunakan confirmatory factor analysis (CFA). Menurut Hair et 
al. (2010) syarat untuk pemeriksaan loading factor adalah: loading 0,30 dipertimbangkan telah memenuhi level minimal; loading 0,40 dianggap lebih baik; dan untuk loading $\geq 0$,50 dianggap signifikan secara praktikal. Sedangkan pengujian reliabilitas menggunakan teknik analisis Cronbach's alpha. Menurut Hair et al. (2010), jika koefisien Cronbach's alpha menunjukkan nilai $\leq$ 0,60 maka reliabilitas dinilai buruk, namun masih bisa digunakan untuk lebih lanjut. Kemudian, jika koefisien Cronbach's alpha menunjukkan nilai antara 0,60 sampai dengan 0,70 maka reliabilitas dapat diterima, selanjutnya jika koefisien Cronbach's alpha menunjukkan nilai $\geq 0,80$ maka reliabilitas dinilai baik.

\section{HASIL DAN PEMBAHASAN}

Pada Tabel 1 terlihat bahwa sebagian besar responden bergender perempuan yaitu berjumlah 108 orang atau 51,9\% dari total responden sedangkan sisanya sebanyak 100 perempuan $(48,1 \%)$. Sesuai dengan hasil tabulasi data juga diketahui bahwa sebagian besar responden memiliki tingkatan usia antara 18 tahun sampai dengan 20 tahun yaitu sebanyak 126 orang $(60,6 \%)$ dari total seluruh responden sedangkan responden yang memiliki jumlah paling sedikit adalah mereka yang berusia antara 15 tahun sampai dengan 17 tahun yaitu hanya berjumlah 1 orang atau $30,005 \%$ dari total seluruh responden. Terakhir untuk pengalam menjalankan usaha, sebagian besar responden yakni 88 responden (42,3\%) pernah menjalankan usaha dan hingga saat ini usaha tersebut masih beroperasi.

Tabel 1.

Demografis Responden

\begin{tabular}{lcc}
\hline \multicolumn{1}{c}{ Demografis } & Jumlah & Persentase (\%) \\
\hline Gender & & \\
\hline Laki-Laki & 100 & 48,1 \\
\hline Perempuan & 108 & 51,9 \\
\hline Umur & & \\
\hline $15-17$ tahun & 1 & 0,05 \\
\hline $18-20$ tahun & 126 & 60,6 \\
\hline $21-23$ tahun & 77 & 37,0 \\
\hline diatas 24 tahun & 4 & 1,9 \\
\hline Pengalaman Usaha & 88 & 42,3 \\
\hline Tidak pernah & 38 & 18,3 \\
\hline Pernah namun gagal & 7 & 3,4 \\
\hline $\begin{array}{l}\text { Pernah namun gagal dan memulai lagi } \\
\text { namun tetap gagal lagi }\end{array}$ & 43 & 20,7 \\
\hline Pernah namun hanya karena tugas & 32 & 15,4 \\
\hline
\end{tabular}




\begin{tabular}{lll} 
perkuliahan & & \\
\hline $\begin{array}{l}\text { Pernah dan saat ini usaha / bisnis } \\
\text { masih eksis / beroperasi }\end{array}$ & 88 & 42,3 \\
\hline Sumber: Data dish (2020)
\end{tabular}

Sumber: Data diolah (2020)

Pengujian instrumen pada penelitian ini menggunakan metode Confirmatory Factor Analysis (CFA). Metode CFA bertujuan untuk memastikan bahwa item-item pernyataan yang dirancang valid dan tepat mengukur apa yang semestinya diukur. Selanjutnya, metode KayserMeyer-Olkin Measure of Sampling Adequacy (KMO) dan Bartlett's Test of Sphericity digunakan untuk mengevaluasi kekuatan asosiasi linier diantara butir item dalam matrik korelasi. Skor KMO >0,50 dianggap dapat diterima dan mengindikasikan bahwa uji analisis faktor layak dianalisis lebih lanjut. Seperti yang ditampilkan pada Tabel 2, skor $\mathrm{KMO}=0,651$ (Bartlett's Test of Sphericity: Approx. Chi-Square $=83,390, d f=3$ Sig. at $p<0,000)$ dengan melibatkan model penelitian berupa item-item variabel empati, dukungan sosial, dan minat berwirausaha sosial. Skor KMO telah menunjukkan $\geq 0,5$, dapat disimpulkan bahwa analisis dapat dilanjutkan pada tahapan selanjutnya.

Tabel 2.

\section{Skor KMO}

\begin{tabular}{lcc}
\hline $\begin{array}{l}\text { Kayser-Meyer-Olkin Measure of } \\
\text { Sampling Adequacy }\end{array}$ &, 651 \\
\hline $\begin{array}{l}\text { Bartlett's Test of Sphericity: } \\
\text { Approx. Chi-Square }\end{array}$ & 83,390 \\
\hline \multicolumn{2}{c}{$d f$} & 3 \\
\hline & Sig. &, 000 \\
\hline
\end{tabular}

Sumber: Data diolah (2020)

Tahapan selanjutnya setelah nilai $\mathrm{KMO} \geq 0,5$, $(0,651)$ terpenuhi, maka pengujian validitas instrument penelitian dapat dilakukan. Berdasarkan hasil pengujian CFA, diperoleh dari total keseluruhan instrument yakni 9 item berada pada nilai loading factor $\geq 0,5$ yang menunjukkan instrument tersebut valid (Tabel 3). 
Tabel 3.

Hasil Uji Validitas dengan CFA

\begin{tabular}{cccc}
\hline \multicolumn{4}{c}{ Rotated Component Matrix } \\
\hline \multirow{2}{*}{ Item } & \multicolumn{3}{c}{ Component } \\
\cline { 2 - 4 } & 1 & 2 & 3 \\
\hline EMP1 &, 796 & & \\
EMP2 &, 760 & & \\
EMP3 &, 748 & & \\
\hline SEI1 & &, 718 & \\
SEI2 & &, 796 &, 796 \\
SEI3 & &, 709 &, 745 \\
\hline PSS1 & & & \\
PSS2 & & & \\
PSS3 & & \\
\hline Sumber: Data diolah (2020)
\end{tabular}

Setelah uji validitas dilakukan, tahapan berikutnya ialah melakukan pengujian realibilitas terhadap item-item pernyataan yang sudah dinyatakan valid. Secara umum, berdasarkan Tabel 4 bahwa variabel empati, dukungan sosial, dan minat berwirausaha sosial sudah menunjukkan kecukupan nilai Cronbach's Alpha yakni berada pada nilai $\geq 0,6$ sedangkan variabel minat berwirausaha sosial dinyatakan kurang reliabel namun masih tetap bisa diikutsertakan pada tahapan analisis (Hair et al., 2010).

Tabel 4.

Hasil Uji Realibilitas

\begin{tabular}{lcc}
\hline \multicolumn{1}{c}{ Variabel } & Item & $\begin{array}{c}\text { Cronbach's } \\
\text { Alpha }\end{array}$ \\
\hline Empati & 3 &, 636 \\
\hline $\begin{array}{l}\text { Minat berwirausaha } \\
\text { sosial }\end{array}$ & 3 &, 590 \\
\hline $\begin{array}{l}\text { Dukungan Sosial } \\
\text { Sumber: Data diolah (2020) }\end{array}$ & 3 &, 720 \\
\hline
\end{tabular}

Pengujian hipotesis pada penelitian ini menggunakan analisis regresi linier berganda. Pada tahapan pengujian pengaruh antara empati terhadap minat berwirausaha sosial $\left(\mathrm{H}_{1}\right)$, mengindikasikan bahwa empati tidak berpengaruh positif terhadap minat berwirausaha sosial dikarenakan nilai Sig. at $p \geq 0,05$ yakni 0,288 ( $\mathrm{H}_{1}$ tidak terdukung). Hasil tersebut menujukkan bahwa empati yang dipersepsikan mahasiswa tidak berpengaruh terhadap minat berwirausaha sosial. Hasil ini bermakna bahwa, kepedulian terhadap kondisi sosial yang dipersepsikan oleh mahasiswa tidak mempengaruhi minat mereka dalam berwirausaha sosial.

Selanjutnya, hasil pengujian hipotesis $\mathrm{H}_{2}$ bahwa dukungan sosial berpengaruh positif terhadap minat berwirausaha sosial menujukkan nilai Sig. at $p \leq 0,05$ yakni $0,002\left(\mathrm{H}_{2}\right.$ terdukung). Berdasarkan koefesien regresi menujukkan bahwa dukungan sosial mempengaruhi 
sebesar 31,\% (0,310) terhadap minat berwirausaha sosial. Artinya, empati yang dipersepsikan oleh seseorang berpengaruh positif dan signifikan terhadap minat berwirausaha sosial. Semakin tinggi empati yang dimiliki seseorang maka semakin tinggi pula minat berwirausaha sosial yang dipersepsikan. Rangkuman hasil pengujian hipotesis dapat dilihat pada Tabel 5.

Tabel 5. Hasil Pengujian Hipotesis

\begin{tabular}{llcc}
\hline \multicolumn{1}{c}{ Hipotesis } & $\begin{array}{c}\text { Standardized } \\
\text { Beta Coefficients }\end{array}$ & Sig. \\
\hline $\mathrm{H}_{1}$ & Empati $\rightarrow$ Minat berwirausaha sosial & 0,082 & 0,228 \\
$\mathrm{H}_{2}$ & $\begin{array}{l}\text { Dukungan Sosial } \rightarrow \text { Minat } \\
\text { berwirausaha sosial }\end{array}$ & 0,310 & 0,000 \\
\hline $\begin{array}{l}\text { Note: } * \text { Significant at } p<0,01 \\
\text { Sumber: Data diolah }(2020)\end{array}$ & & \\
\cline { 2 - 3 } Sumber: Data diolah $(2020)$ & &
\end{tabular}

Hasil pengujian pernyataan hipotesis $\mathrm{H}_{1}$ menujukkan tidak terdukung. Temuan tersebut tidak konsisten dengan hasil penelitian yang dilakukan oleh (Hockerts, 2017) dimana empati ditemukan berpengaruh positif (direct effect) terhadap minat berwirausaha sosial. Meskipun demikian, temuan ini mendukung argumentasi dari perspektif Planned Behaviour Theory menunjukkan bahwa perilaku niatan seseorang tidak langsung dipengaruhi oleh variabel antecendent, namun dimediasi (mediators) oleh niatan sikap seseorang (Tiwari et al., 2017b). Tiwari et al., (2017b) sendiri telah merumuskan model dimana empati tidak secara langsung mempengaruhi minat berwirausaha sosial namun pengaruh tersebut dimediasi oleh faktor lain. Meskipun demikian, ketidakterdukungan hasil penelitian ini mungkin saja disebabkan oleh faktor lain yang tidak diteliti. Selain itu, diduga empati yang dimiliki oleh seseorang yang telah memiliki pengalaman bidang bisnis akan berbeda dengan empati yang dimiliki dikalangan mahasiswa.

Pada hasil pengujian $\mathrm{H}_{2}$ dimana pernyataan hipotesis yakni empati berpengaruh positif terhadap minat berwirausaha sosial menunjukkan terdukung. Hasil penelitian ini mengkonfirmasi bahwa empati yang dipersepsikan oleh seseorang dapat mempengaruhi sikap terhadap ATB secara signifikan. Semakin tinggi tingkat empati seseorang, semakin menunjukkan kepeduliannya terhadap masalah sosial yang kemudian diniatkan dalam sikap untuk berniat menjadi seorang wirausahwan sosial. Hasil ini selaras dengan pandangan (Mair \& Naboa, 2006) bahwa empati juga bertindak sebagai sikap individu terhadap perilaku wirausahawan sosial. Temuan ini sekaligus mengkonfirmasi hasil penelitian oleh (Ayob et al., 2013) bahwa empati merupakan antaceden penting dalam menentukan sikap dan perilaku kewirausahaan sosial. 
Selanjutnya, hasil penelitian ini konsisten dengan hasil penelitian yang dilakukan oleh Hockerts (2015) dimana dukungan sosial ditemukan berpengaruh positif (direct effect) terhadap minat berwirausaha sosial. Semakin tinggi tingkat dukungan sosial, semakin menunjukkan kepeduliannya terhadap masalah sosial yang kemudian diniatkan dalam sikap untuk berniat menjadi seorang wirausahawan sosial. Namun demikian, hasil penelitian ini tidak selaras dengan pandangan Mair \& Naboa (2006) dan Hockerts (2015) bahwa dukungan sosial tidak secara langsung sebagai perilaku yang langsung (direct) terhadap minat berwirausaha sosial.

\section{PENUTUP}

Hasil penelitian telah menujukkan bahwa empati tidak berpengaruh langsung terhadap niat berwirausaha sosial. Hasil penelitian ini sekaligus mengkonfirmasi model Mair \& Naboa (2006) dimana empati tidak berpengaruh langsung terhadap minat berwirausaha sosial. Secara praktis, Universitas Bung Hatta disarankan untuk memberikan muatan khusus pada mata kuliah kewirausahaan yakni kewirausahaan sosial. Melalui konsep kewirausahaan sosial yang diusung tersebut, mahasiswa diharapkan dapat menjadi agen-agen perubahan di masyarakat. Agen perubahan yang memberi dampak perubahan sosial yang signifikan terhadap kemajuan sosial ekonomi masyarakat secara luas.

Keterbatasan dari penelitian ini meliputi objek penelitian yang hanya pada mahasiswa fakultas ekonomi dan bisnis Universitas Bung Hatta. Karenanya, generalisasi hasil penelitian perlu ditingkatkan dengan memperluas scope objek penelitian pada multidisiplin sehingga dapat memberikan generalisasi yang lebih baik.

Selain itu, penelitian selanjutnya disarankan untuk menguji faktor lain pada variabel minat berwirausaha sosial dengan menggunakan model (Mair \& Naboa, 2006) seperti konstruk emosional kognitif yang terdiri dari empati sebagai faktor emosional dan penilaian moral sebagai faktor kognitif dan persepsi kemungkinan akan dilakukan (perceived feasibility) dipengaruhi oleh penilaian moral sebagai faktor kognitif; dan kelayakan yang dirasakan dipengaruhi oleh seseorang atau sesuatu yang memungkinkan sesuatu terjadi (enablers) yang terdiri dari efikasi diri dan dukungan sosial. Disisi lain, penelitian selanjutnya juga perlu menguji variabel kecerdasan emosional dimana dalam dimensi tersebut juga terdapat unsur empati. 


\section{DAFTAR PUSTAKA}

Abu-saifan. (2012). Social Entrepreneurship: Definition and Boundaries. Technology Innovation Management Review, 2 (2): 22-27.

Ajzen, I. (1975). Belief, attitude, intention and behaviour: An introduction to theory and research. Reading, MA: Addison-Wesley. Reading, MA: Addison-Wesley.

Ajzen, I. (1991). The theory of planned behavior. Organizational Behavior and Human Decision Processes, 50 (2): 179-211.

Ayob, N., Yap, S., Sapuan, A., \& Rashid, A. (2013). Social Entrepreneurial Intention among Business Undergraduates: An Emerging Economy Perspective 1, Gadjah Mada International Journal of Business, 15 (3): 249-267.

Bocken, at al. (2014). A Literature And Practice Review to Develop Sustainable Business Model Archetypes A Literature And Practice Review to Develop Sustainable Business Model, Journal of Cleaner Production, 65: 42-56. doi:10.1016/j.jclepro.2013.11.039.

Buku Pedoman Merdeka Belajar-Kampus Merdeka. (2020). Direktorat Jenderal Pendidikan Tinggi Kementerian Pendidikan dan Kebudayaan Republik Indonesia

Boons, F., \& Lüdeke-freund, F. (2013). Business models for sustainable innovation : state-ofthe-art and steps towards a research agenda, Journal of Cleaner Production, 45: 9-19. doi:10.1016/j.jclepro.2012.07.007

Desa, G. (2010). of a Research Field in Emergence. In Values and Opportunities in Social Entrepreneurship (pp. 6-28). New York: Palgrave Macmillan.

Cooper, Donald., Schinder, P. (2014). Business research methods. New York: McGraw-Hill Companies.

Hair, F. (2010). Multivariate Data Analysis. 7th ed. Upper Saddle River, NJ: Prentice Hall.

Hibbert, S. A., Hogg, G., \& Quinn, T. (2005). Social entrepreneurship : Understanding consumer motives for buying The Big Issue. Journal of Consumer Behavior, 4(3), 159172.

Hockerts, K. (2015). Antecedents of Social Entrepreneurial Intentions : A Validation Study The Social Entrepreneurial Antecedents Scale ( SEAS ): A Validation Study. Social Enterprise Journal, 11 (3): 260-280. doi:10.5465/AMBPP.2013.16805abstract

Hockerts, K. (2017). Determinants of Social Entrepreneurial Intentions, Social Entreprise Journal, 105-130. doi:10.1111/etap.12171

Hulgard, L. (2010). Discourses of Social Entrepreneurship-Variations Of The Same Theme ?. EMES Euroupean Research Network, (10), 1-21. 
Mair, J., Robinson, J., \& Hockerts, K. (2006). Social Entrepreneurship. New York: Palgrave Macmillan Houndmills.

Rashid, N. S., Sarkam, S. F., Junaini, N., Yaacob, A., Mustapha, M., Hussain, N. J., \& Azis, R. A. (2018). Factors Influencing Student's Social Entrepreneurship Intention : A Case of Duta Jauhar Program Factors Influencing Student's Social Entrepreneurship Intention: A Case of Duta Jauhar Program, International Journal of Academic Research in Business and Social Science, 8 (8): 1307-1321. doi:10.6007/IJARBSS/v8-i4/4538

Tiwari, P., Bhat, A. K., \& Tikoria, J. (2017a). Predictors of social entrepreneurial intention: an empirical study, South Asian Journal of Business Studies, 6 (1): 1-25. doi:10.1186/s40497-017-0067-1

Tiwari, P., Bhat, A. K., \& Tikoria, J. (2017b). The role of emotional intelligence and selfefficacy on social entrepreneurial attitudes and social entrepreneurial intentions, Journal of Social Entrepreneurship,0676(September). doi:10.1080/19420676.2017.1371628

Utomo, H. (2014). Menumbuhkan Minat Kewirausahaan Sosial. Among Makarti, 7 (14): 1-16. 